ТОМЧУК О. А.

\title{
НАПРЯМИ І ФОРМИ ВОЛОНТЕРСЬКОГО РУХУ В ДОПОМОГУ ЗБРОЙНИМ СИЛАМ УКРАЇНИ У 2014-2018 pp.
}

Аналізуються напрями і форми волонтерського руху в допомогу Збройним Силам України, який розгорнувся після агресії Російської Федерації проти України у 2014 році. Визначається, що пік піднесення волонтерського руху зафіксовано у 2015 р., коли на території України свою діяльність поширювали понад двісті 3 половиною відомих волонтерських ініціативних об'єднань. Різноманітні за походженням і соціальним складом волонтерські об'єднання скеровували свою роботу в кількох пріоритетних напрямах, основним з яких були фінансова, гуманітарна підтримка воїнам АТО.

Ключові слова: волонтер, волонтерський рух, Антитерористична операція.

Актуальність проблеми зумовлена широким розмахом волонтерського руху на допомогу Збройним Силам України, яка й надалі є вагомим фактором у збройній відсічі агресії Російської Федерації. Революція Гідності та російське вторгнення до Криму, Донбасу сприяли формуванню організованої громадської взаємодопомоги спочатку революціонерам Майдану, а потім Збройним Силам України (далі - ЗСУ), які потребували докорінного матеріально-технічного забезпечення i морально-психологічного зміцнення.

Активна фаза війни Росії проти України розпочалася у час найбільшої слабкості державного управління держави (втеча колишнього керівництва країни), певної деморалізації силових структур, що унеможливило ефективну реакцію української влади. Однак за короткий час після Свромайдану в країні були проведені демократичні вибори, поновлені владні структури, мобілізовані наявні демографічні та матеріально-технічні ресурси для протидії агресії. Насамперед реанімовано військову галузь України, яку свідомо розвалювали ставленики Кремля попереднього режиму.

Метою даної публікації є визначення основних напрямів та форм волонтерського руху на допомогу ЗСУ під час збройної агресії Російської Федерації на Сході України.

Томчук Олександр Анатолійович, ад’юнкт науково-дослідної лабораторії (військово-історичних досліджень) Наукового центру Сухопутних військ Національної академії сухопутних військ імені гетьмана Петра Сагайдачного, м. Львів.

(C) Томчук О.А., 2018 
Огляд джерел та літератури. Проблема українського військового волонтерства активно розглядалася у публіцистичній літературі, однак істориками наукове опрацювання теми лише починається. Так у друку і на сайті Національного інституту стратегічних досліджень 3'явилася аналітична доповідь, де розглянуто зарубіжний досвід волонтерської діяльності та охарактеризовано сучасне становище українського волонтерства в умовах зовнішньої агресії [1]. На Міжнародній науковій конференції, проведеній у Національній академії сухопутних військ імені гетьмана Петра Сагайдачного, військові історики Ю. Бураков, О. Турчак та П. Ткачук розглянули інформаційно-пропагандистську діяльність волонтерського руху допомоги Збройним Силам України у ході російсько-української війни [2].

Досить докладно розглядає українське волонтерство як нову форму громадянської активності О.С. Мандебура-Нога [3]. Крім істориків, тему волонтерства вивчають спеціалісти 3 державного управління, соціологи, політологи.

Основним джерелом наукового дослідження теми $є$ сайти волонтерських організацій України, численна вітчизняна преса, результати соціологічних опитувань, спогади та інтерв'ю учасників волонтерського руху на допомогу ЗС України.

Виклад основного матеріалу. Події української Революції Гідності (осінь 2013 - зима 2014 рр.), зокрема, перехід іï у фазу збройного протистояння після брутального розгону студентського Євромайдану, призвели до якісно нового розвитку унікального волонтерського руху допомоги, підтримки та єдності українських громадян. Мільйони людей всієї України рішуче стали на підтримку київського Майдану, організували власні майдани у своїх населених пунктах, протестуючи проти антиукраїнського режиму президента В. Януковича. Ці мільйони людей, окрім особистої участі у протестних мітингах, активно підтримали майданівців їжею, водою, ліками, засобами гігієни, захисту, теплими речами, грошима тощо.

20 лютого 2014 р. розпочалася збройна агресія Російської Федерації проти України. Загарбання Криму та частини території українського Донбасу призвели до війни на Сході України. У 2014 р. найгострішими проблемами Української армії та загалом силовиків у зоні проведення АТО були відсутність одягу та взуття, засобів захисту та спецзасобів, засобів гігієни, ліків, незадовільне 
харчування. Втім, вже в кінці 2014 р. українські волонтери вийшли на вищий рівень допомоги та оснащення армії, почавши проектувати та виготовляти безпілотні літальні апарати, спецтехніку, розробляючи системи, зокрема, інноваційну технологічну систему артилерійського ведення вогню АРТА, винайшовши новітні системи виготовлення маскувальних сіток (не способом плетіння) тощо.

Російська агресія, розгортання всенародного руху в допомогу ЗСУ змусило урядові кола переглянути бюджет країни щодо збільшення видатків на оборону. У 2014 - 2016 рр. на фінансування українського війська було виділено більше коштів, аніж за всі роки незалежності. Відтак ЗСУ зміцнилися і кількісно, і якісно. Як засвідчили вишколи на Яворівському (Львівщина) та інших полігонах, а також бої в зоні АТО, військові, прикордонники і нацгвардійці, насамперед контрактники, стали майстернішими, покращилася якість їх амуніції та озброєння. Технічні потреби армії задовольняли не лише державні військові заводи у Києві, Житомирі, Харкові, Львові, але й приватні бізнес-структури.

Новітні розробки національних виробників озброєння та військової техніки для ЗСУ продемонстрували 24 серпня 2016 і 2017 років у Києві на парадах на честь Незалежності та 6 грудня 2016 р. у Львові на честь Дня захисника Вітчизни. Останній організовано Львівським гарнізоном, насамперед Національною академією сухопутних військ імені гетьмана Петра Сагайдачного (начальник - генерал-лейтенант П.П. Ткачук). Чимало викладачів та випускників Національної академії сухопутних військ виявили мужність у боях на Донбасі. Зокрема, перший заступник начальника Академії, досвідчений спецназівець, що пройшов вишкіл у США та у миротворчій місії в Афганістані, генерал-майор I. Гордійчук проявив мужність в зоні АТО, за що отримав звання Героя України і після видужання від важкого поранення очолив Військовий ліцей ім. І. Богуна [4].

Організацією Об'єднаних Націй у грудні 2014 р. проведено дослідження на тему: «Волонтерський рух в Україні». Встановлено, що майже чверть громадян України мали певний досвід волонтерства, або сприяли їх роботі; 9 \% українців почали займатись волонтерством внаслідок початку російської агресії у 2014 р. Якщо до Революції Гідності актуальним для волонтерів була підтримка соціально незахищених верств населення, то 3 початком війни $70 \%$ волонтерів зосередилися на підтримці українських 
бійців та армії в цілому, ще частина сприяла вирішенню потреб внутрішньо переміщених осіб з Криму та Донбасу. Також дослідження зафіксувало, що більшість волонтерів мають вищу освіту, та значна частина належить до середнього класу [5].

Найбільше піднесення волонтерського руху зафіксовано у 2015 р., коли на території України свою діяльність поширювали понад двісті 3 половиною знаних волонтерських ініціативних об'єднань. Зазвичай в обласних центрах поставали своєрідні координаційні центри, що згуртували ряд громадських об'єднань у спільному прагненні допомогти українським воякам на Сході. Загалом різноманітні за походженням і соціальним складом волонтерські об'єднання скеровували свою роботу в кількох пріоритетних напрямах, основним 3 яких була фінансова, гуманітарна підтримка воїнам АТО. Важливою складовою роботи волонтерів стала моральна та матеріально-технічна підтримка демобілізованих військових та їх сімей.

Організаційне оформлення та робота волонтерських організацій відбувались у різноманітний спосіб: від професійних, громадських, освітніх об’єднань, коли починалося, і з ініціативи однієї або кількох людей, не пов'язаних між собою, як це було у Львові, коли щовівторка, щочетверга i щосуботи біля пам'ятника королю Данилу волонтери збирали допомогу для земляків-добровольців. Ініціатором таких зборів була Л. Возняк - волонтер спільноти «Допоможи фронту», юрист за освітою, а заразом молода мама двох дітей.

Як згадувала сама волонтерка: «Почалося все 3 того, що одного разу я прочитала про те, що хлопці (воїни АТО) не мають шкарпеток... Коли я це прочитала, одразу ж написала, що о такій-то годині буду стояти біля короля Данила збирати шкарпетки. I воно потім якось закрутилося. Спочатку стояла сама, попросила подругу, щоб підстрахувала на випадок, якщо малий прокинеться. Потім прийшла ще одна жіночка. А коли збір набрав більших масштабів, люди просто приходили і залишалися. Кожного разу приходять одні і ті ж люди -6-8 осіб, але завжди є достатня кількість, щоб допомагати» [6].

Система волонтерського руху функціонувала завдяки iї людським ресурсам. Традиційно науковці застосовують класифікацію добровільних помічників в Україні, поділивши їх на три умовні групи в залежності від їх причетності до певної організаційної структури:

1) волонтери, які працюють при Центрах соціальних служб;

2) волонтери, які є членами різних громадських організацій;

3) волонтери, які представлені іншими категоріями населення. 
У пік розвитку волонтерського руху середини 2015 р. в Україні нараховувалося понад 250 волонтерських організацій, що спеціалізувалися на вирішенні проблем, породжених російсько-українським протистоянням у Криму та на Донбасі. Координатор Ради волонтерів при Міністерстві оборони Д. Ахрамія зауважив: «Зібрати статистику було дуже складно, але враховуючи дані 3МI, реєстрів Мінсоцполітики, а також інформацію, подану Державними облдержадміністраціями, я нарахував 14,5 тисяч волонтерів, які професійно і постійно займаються цією діяльністю, і більше 2,5 тисяч організацій (дані мобільних операторів, Приватбанку та інші джерела). Також більше 1,5 мільйона українців хоча б один раз допомагали армії» [7].

Зрозуміло, що чисельність волонтерів та організацій постійно змінювалася. Багато 3 них виникли як місцеві, регіональні. Відповідно свої зусилля для допомоги українській армії географічно обмежували від області до окремої територіальної громади. Серед них відзначимо ГО «Суспільні ініціативи Козятинщини», Благодійну організацію «Фонд громади Житомир», Громадську спілку м. Полтави «Громада Полтави», 39 жіночу сотню самооборони м. Кривий Ріг та ін. До цього переліку слід додати «Полтавський батальйон небайдужих», що допомагав мобілізованим військовим, добровольчим загонам «Азов», «Донбас», «Дніпро», «Айдар», медикам, які вирушали у зону АТО, а також бійцям батальйону МВС «Полтава».

Окремі місцеві громади, не створюючи власних волонтерських структур, активно співпрацювали 3 великими волонтерськими об'єднаннями. Показовою є історія містечка Ямпіль Донецької області, звільненого українськими військами від російських окупантів у 2015 р., місцева влада якого всіляко сприяла переселенцям 3 тимчасово окупованих територій, залучаючи як місцевих волонтерів, так і всеукраїнський благодійний фонд «Соціальна співпраця», головним пріоритетом якого було впровадження Благодійної Ініціативи «Турбота \& Підтримка», що передбачало декілька напрямів співпраці з місцевою владою м. Ямпіль, а саме:

- збір речей для біженців із зони АТО;

- підтримка хворих дітей;

- адресна гуманітарна допомога сім'ям, що знаходилися у скрутному матеріальному становищі. 
Збір речей для біженців розпочався як відгук на потреби жертв терористичних дій влади маріонеткової «ДНР». Відтак Ямпіль зумів повернутися до мирного життя та організовував допомогу іншим містам Донбасу - Шахтарську, Горлівці, 3 яких прибували переселенці [8].

Варіанти участі українських громадян у вирішенні проблем забезпечення та якісного озброєння армії, загалом українські волонтерські ініціативи відрізняються великим розмаїттям способів і методів збору коштів і загалом напрямів допомоги.

Загалом можна виділити наступні напрями волонтерської діяльності:

- допомога конкретним військовим частинам у зоні проведення бойових дій (закупівля та передача автомобілів, плетіння маскувальних сіток та кікімор, пошиття обмундирування, виготовлення і купівля бронежилетів, бронешоломів; інше);

- діяльність так званої «картографічної сотні» - створення волонтерами сучасних мап для військових, купівля і постачання вартісного електронного обладнання, тепловізорів;

- високотехнологічний напрям, а саме розробка програмістамиволонтерами для Збройних Сил спеціального софту, який не лише скорочує час для здійснення пострілу, але й збільшує точність влучання (так звана система для артилеристів ГІС «АРТА», постачання безпілотних літальних апаратів;

- медичний та реабілітаційний напрям;

- ремонтне волонтерство (ремонтні роботи 3 відновлення військової техніки та важкої воєнної техніки (танків, машин, бронетранспортерів);

- «чорний тюльпан» (передача тіл загиблих волонтерам як представникам української сторони); участь у пошукових роботах безвісти зниклих військовослужбовців;

- меморіальний напрям - вшанування пам'яті військових, які загинули на Сході України. Волонтери встановлюють меморіальні дошки загиблим воїнам (зокрема, на школах) та облаштовують куточки слави на їхню честь; волонтерами створена «Книги пам'яті полеглих за Україну»;

- забезпечення військовослужбовців якісним харчуванням поширена по всій Україні так звана «кулінарна сотня», що було особливо актуальним у перший рік ведення бойових дій, але залишається й донині популярним серед бійців на фронті; 
- переселенський напрям (створення центрів допомоги, центрів адаптації, допомога із придбанням та пошуком житла i роботи, збір гуманітарної допомоги для переселенців (харчі, одяг, речі, предмети домашнього вжитку), соціальна адаптація внутрішньо переміщених осіб, створення волонтерами електронної бази даних переселенців;

- збір та перевезення гуманітарної допомоги цивільному населенню, яке проживає на території проведення бойових дій;

- вивезення цивільного населення із фронтової та прифронтової зони (наприклад, Дебальцеве, Мар'їно та інших гарячих точок);

- залучення волонтерів до виконання державних функцій (наприклад, контроль і супроводження всіх процесів розмитнення гуманітарної допомоги; «волонтерський десант» у Міністерстві оборони України та ряд інших фактів).

Види та способи медичної допомоги не такі різнорідні, але i тут можна виділити різні напрями. Створені i функціонують благодійні організації, орієнтовані суто на професійну медичну допомогу пораненим. Як приклад наведемо благодійну організацію «Біотех-реабілітація поранених/Biotech-rehabilitation of injured people» - український соціальний проект для поранених в АТО (лікування травм кісток). «Біотех-реабілітація» працює спільно $з$ медичною компанією Ilaya, яка застосовує інноваційні сучасні технології. Суть лікування - подолання наслідків поранень у бійців та підготовка місць травм для відновлення клітин за допомогою клітинних технологій. Клініка приймає на лікування поранених, навіть із задавненими травмами, які не лікуються традиційними методами. Волонтери, меценати і благодійники перераховують кошти. Суми переказів різні - від 50 грн. до 90800 грн., вся ця інформація оприлюднюється як на офіційній веб-сторінці організації, так і в соціальних мережах [9].

Організатор благодійного проекту «Біотех-реабілітація поранених» - засновник та генеральний директор компанії „Ilaya” О. Шершньов. Партнери проекту - медична компанія „Ilaya” (виконання операцій 3 використанням клітинних технологій), портал - narodniy.org.ua (залучення коштів для фінансування операцій), об'єднання матерів та дружин військовослужбовців «Оберіг» (збір інформації про поранених, які потребують допомоги в рамках проекту). У рамках проекту допомога надається усім постраждалим на війні - і військовим, і мирним мешканцям 
iз зони бойових дій (які складають меншість). Якщо людина бажає отримати таку допомогу, вона заповнює онлайн-анкету, лікарі медичного центру „Іlауа” визначають доцільність проведення реабілітації саме за допомогою клініки. У випадку позитивного рішення лікарів організатори збирають необхідні кошти і проводять лікування у цьому медичному центрі. До того ж, клініка надає бійцям спеціальні знижки - навіть 48,15\% [9].

Висновки. 3 початком російської агресії Україна демонструє унікальний приклад справжнього всенародного волонтерського руху, що свідчить про зрілість громадянського суспільства i патріотичний настрій більшості населення. Безперечно, допомога волонтерів Збройним Силам відіграла величезне значення для відсічі ворогу, зламала загарбницькі плани Москви щодо окупації України. Наведені вище дані лише окреслюють загальні напрями волонтерської роботи, вони не є повними і остаточними. У свою чергу, кожен із напрямів має власні інваріанти діяльності, шляхи реалізації максимально повного задоволення армійських i фронтових потреб, а також допомоги пораненим, переселенцям та іншим вразливим соціальним групам.

1. Горєлов Д., Корнієвський О. Волонтерський рух: світовий досвід та українські громадянські практики, Київ, 2015, - 36 с.

2. Ткачук П., Бураков Ю., Турчак О. Інформаційнопропагандистська діяльність волонтерського руху допомоги Збройним Силам України у ході російсько-української війни, Перспективи розвитку озброєння та військової техніки Сухопутних військ: Збірник тез доповідей Міжнародної науково-технічної конференції, - Львів 2017, - С. 365.

3. Мандебура-Нога О.С. Волонтерство як нова форма громадської активності в Україні, Трансформація політичних інститугів України: проблеми теорії і практики. - Київ, 2016, C. 243-277.

4. Генерал Гордійчук: «Ми щодня стаємо сильнішими, а «імперія зла» - слабшою» // Високий замок. - 2016. - 612 жовтня.

5. Між війною і соборністю. Соціокультурна інтеграція та адаптація переселенців 3 Донбасу та Криму. Західноукраїнський вектор / [відп. ред. М. Литвин]. - Львів, 2017. C. 7-9.

6. Волонтери фронту: Хто у Львові допомагає військовим [Електронний ресурс]. - Режим доступу: http://tvoemisto.tv/news/volontery_frontu_hto_u_lvovi_dopo magaie_viyskovym_66020.html 
7. В Україні 14,5 тис. волонтерів постійно допомагають армії - Ахрамія [Електронний ресурс]. - Режим доступу: https://www.radiosvoboda.org/a/ news/27039296.html

8. Благодійна ініціатива «Турбота, підтримка» [Електронний pecypc]. - Режим доступу: https://www.facebook.com/pg/Charityinitiative Care Support/ about/?ref=page internal

9. People's Projekt com. Всеукраїнський центр волонтерів. Офіційний сайт «Біотекс- реабілітація поранених» [Електронний ресурс]. - Режим доступу: https://www.peoplesproject.com/biotech

Надійшла до редколегії 27.12.2017 p.

Рецензент: А.Ф. Лозинський, кандидат історичних наук, доцент кафедри гуманітарних дисциплін та соціальної роботи, Львівський державний університет безпеки життєдіяльності, м. Львів.

\section{Tomchuk OLeksandr}

Directions and forms of volunteer movement to assist the Armed Forces of Ukraine in 2014-2018

The article analyzes directions and forms of the volunteer movement to assist the Armed Forces of Ukraine, which was launched after the aggression of Russian Federation against Ukraine in 2014. It is determined that the peak of growth of volunteer movement was recorded in 2015 when more than two hundred and half of the well-known volunteer initiative associations extended their activities on the territory of Ukraine. Different in origin and social composition volunteer associations organized their work in several priority areas, the main task was the financial and humanitarian support to ATO soldiers.

Key words: volunteer, volunteer movement, antiterrorist operation. 